\title{
CASE COMMENTS
}

\section{ADMINISTRATIVE LAW-PRIVATIVE CLAUSES-THE RAMMELL AND FARRELL CASES}

With the major role played by government in society today the administrative board has taken on increased importance in both a qualitative and a quantitative sense. It was early decided that the courts should exercise a supervisory control over these boards in much the same way as the Court of King's Bench used to supervise courts of inferior jurisdiction.

Since the rationale for setting up such bodies in the first place was their greater suitability to perform certain tasks than the courts, legislative bodies of ten attempted to control judicial review. This was certainly the case when courts upset decisions of administrative tribunals for what the legislators considered petty or technical faults. The result was an attempt to regulate review by the courts by inserting privative clauses into the authorizing statute.

Two recent decisions of the Supreme Court of Canada, Rammell v. Workmen's Compensation Board' and Farrell v. Workmen's Compensation Board" have failed to clear much of the confusion in this area of privative clauses. In both cases the Court was presented with a situation and a statute which could not have raised the issue more clearly. In the Farrell case the question was summarily disposed of in several paragraphs without anything resembling an examination of the authorities; while in the Rammell case, heard one day later, and dealing with the same British Columbia Workmen's Compensation Act, ${ }^{3}$ the question of the privative clause was not even mentioned.

The purpose of this comment is to review the law in this area and assess the Canadian position today. There is little value in canvassing the mass of provincial decisions." Views may be found therein which mean all things to all men." Rather, emphasis will be placed on basic principles as applied in the classic English cases, Supreme Court of Canada decisions, and certain sound provincial opinions.

In the Farrell case, an appeal from the British Columbia Court of Appeal, the appellant's husband, a hospital workman, was found dead after having engaged in some physical exertion which his work required. The appellant's claim for relief under the Workmen's Compensation Act was denied on the basis that the death was not the result of an accident arising out of and in the course of his employment. The Supreme Court

1 [1962) S.C.R. 85.

2 [1962] S.C.R. 48.

3 R.S.B.C. 1948 , c. 370, s. $76(1)$. Reenacted R.S.B.C. 1960 , c. 413 , c. 413 , s. $77(1)$.

- See Laskln (1952) 30 C.B.R. 381.

5 Es. the Sudgment of O'Halloran J. In Rammell v. Workmen's Compensation Baard, (1961) 35 W.W.R. 145 (B.C.C.A.) in whlch he upset the declston of the Board on at least four different grounds Including fallure to hold a hearlng. 
of Canada rejected the appellant's argument that the board had exceeded its jurisdiction and dismissed the appeal. The revelant section of the Act for our purposes is section $76(1)$ :

76(1). The Board shall have exclusive jurisdiction to inquire into, hear, and determine all matters and questions of fact and law arising under this Part, and the action or decision of the Board thereon shall be final and conclusive, and shall not be open to question or review in any Court, and no proceedings by or before the Board shall be restrained by injunction, prohibition, or other process or proceedings in any Court or be removable by certiorari or otherwise into any Court; and without restricting the generality of the foregoing the Board shall have exclusive jurisdiction to inquire into, hear, and determine:

(a) The question whether an injury has arisen out of or in the course of an employment within the scope of this Part.

Mr. Justice Judson, in delivering the unanimous judgment of the court held that the issue of whether there was an accident arising out of and in the course of employment:

$\ldots$ is unquestionably within the jurisdiction of the Board under Part I of the Act and even if there was error, whether in law or fact, it was made within the exercise of the jurisdiction and is not open to any judicial review, including certiorari. $0^{\circ}$

Later he stated that all questions which arise for decision under Part I of the Act:

... by the very terms of section 76 (1) are within the exclusive jurisdiction of the Board and on which the decision of the Board is final:

It is surprising that in the Rammell case where the issue was virtually identical the exclusionary clause was not even alluded to. There the respondent's husband, an employee of a logging operation at Homfray Creek, British Columbia, was drowned while crossing by boat from the job site to Campbell River. The Workmen's Compensation Board decided that he did not die as a result of an accident arising out of and in the course of his employment and rejected the widow's claim for compensation. The British Columbia Court of Appeal ${ }^{8}$ granted certiorari. The Supreme Court of Canada (Cartwright J. dissenting) allowed the appeal of the Board. The issue of the privative clause is touched only by implication. Mr. Justice Judson stated that:

... no issue going to jurisdiction is ralsed here. Consequently, the Court of Appeal should not have quashed the decision of the Board and issued the mandatory order."

The logical deduction is that had there been an issue going to jurisdiction then the court would have "quashed the decision of the Board" notwithstanding the presence of section $77(1) .^{10}$

One could be excused from feeling on a reading of the two cases that there is something contradictory. It would appear that in the Farrell case the court is saying that because of section $76(1)$ the decision of the Board is not open to judicial review, while, one day later, in the Rammell case the court is in fact reviewing and implying that the decision could be quashed if there were an issue going to jurisdiction.

The conflict is more apparent than real. The true meaning of the decisions can only be understood by distinguishing between; (1) the

6 Supra, n. 2, at 51 .

7 Ibid.

$8(1960-61), 33$ W.W.R. 433

o Id., at 92 .

10 Formerly s. 76(1). Reenacted R.S.B.C. 1960, c. 413, s. $77(1)$. 
comprehensive form of privative clause which purports on its face to exclude any judicial review whatsoever ${ }^{12}$ and; (2) the more specific form of clause which vests exclusive jurisdiction in a tribunal to determine certain facts.." The privative clause in the Rammell and Farrell cases is a combination of both of these.

Each of these clauses has a different legal effect. It is submitted that at present in Canada the comprehensive "no certiorari" clause is not sufficient to exclude judicial review when there is an issue going to jurisdiction. However, there is a partial exception when the statute, in addition, gives the tribunal exclusive jurisdiction to determine its own jurisdictional facts. Both forms of clause require separate consideration. THE COMPREHENSIVE "NO CERTIORARI" CLAUSE

Attempts were made as early as $\mathbf{1 6 7 0}$ in the English Conventicle Act ${ }^{13}$ to exclude judicial review. Section 6 provided:

6. No other Court whatsoever shall intermeddle with any causc or causcs of nppeal upon this Act; but they shall be finally determined in the quartersessions only.

In referring to this section Lord Mansfield said:

There is no colour that these negative words should take away the jurisdiction of this Court to issue writs of certiorari. They will perhaps take away the writ of error that has been mentioned. But this Court has an inherent power to issue certioraris in order to keep all inferior Courts within due bounds unless expressly forbid (sic) so to do by the words of the law. If the justices have done right below you may shew it, and quash the certiorari. But if there be the least doubt, this Court will grant the writ.'t

In 1826 it was held that certiorari would lie even where the statute expressly took it away if the tribunal lacks or exceeds jurisdiction because of the nature of the subject or failure to observe essential preliminaries." The reason was that the "allowance was not in pursuance of the powers given in the statute". Since that time the English courts have been consistent in granting certiorari despite wide privative clauses in cases of; (1) manifest defect of jurisdiction in the tribunal; or (2) manifest fraud in the party obtaining the order of the tribunal-the two tests set down by the leading Privy Council decision on this subject.1" Unfortunately there have been no judicial pronouncements on this area by the House of Lords largely because, unlike in Canada, statutory exclusion of the right to apply for certiorari is no longer the usual device adopted in England for depriving superior courts of the power to review.":

The thread of English decisions was picked up in Canada as early as 1859 when the Queen's Bench Division of Ontario, in referring to the prerogative writ, held that:

- . this remedy would be accessible even if a statute had declared that a certiorari shall not issue because that prohibition would not be held to apply when the justices or sessions had entertained a matter not within their jurisdiction. ${ }^{\text {ha }}$

11 Eg. the mlddle part of section $76(1)$ whlch reads $" . .$. and the action or dectsion of the Bonrd thereon shall be final and conclusive, and shail not be open to question or review in any Court. and no proceedings by or before the Board shall be restralned by injunction, prohibition, or other process or proceedints in any Court or be removable by certlorarl or otherwise into any Court ....

$1:$ Eg. the firgt part of section 76 (1) which reads "The Board shall have exclualve Jurisdiction to inquire into, hear, and determine all matters and questions of fact and Jaw arising under this part...."

1:: 22 Car. 2 , c. 1 .

1t The King v. Reeve, Morris, Osborne, (1760) I Bl.W. 231.233.

1.J R. v. Somersetshire JJ. (1826) 5 B\&C.816.

11 Colonial Bank of Australasia $v_{.}$Willan (1855) 5 El. \& Bll. 49.

1: See S. A. De Smith. (1955) M.L.R. 575.

isa Hespeller v. Shaw (1859) 16 U.C.Q.B. 104 at 105.106. 
The first case in which the issue of the comprehensive privative clause :aced the Supreme Court of Canada squarely was Toronto Newspaper Guild v. Globe Printing Co." The court was unequivocally unanimous that such clauses are ineffective to exclude review where there is a lefect in jurisdiction.

It was held in that case that the Ontario Labour Relations Board had declined jurisdiction in refusing to allow the respondent to cross-examine the union secretary in certification proceedings. The decision of the Board was quashed by certiorari despite section 5 of the Ontario Labour Relations Act $^{19}$ which read:

5. Subject to such right of appeal as may be provided by the regulations, the orders, decisions, and rulings of the Board shall be final and shall not be questioned or reviewed nor shall any proceeding before the Board be removed, nor shall the Board be restrained. by injunction, prohibition, mandamus, quo warranto, certiorari, or otherwise by any court, but the Board may, if it considers it advisable to do so, reconsider any decision or order made by it and may vary or revoke any such decision or order.

In upholding the quashing order of the Ontario Court of Appeal," Mr. Justice Kerwin stated:

Sections similar to section 5 of the Act, although differing in form, have been enacted by legislative bodies from time to time but it is unnecessary to set forth the decisions in which they have been considered because, if jurisdiction has been exceeded; such a section cannot avail to protect an order of the Board; and $I$ understand that to be conceded by counsel for the appellant." $=1$

The latter part of the statement indicates the only weakness of the decision for our purposes as counsel for the appellant apparently did not argue the exclusionary clause. However, there was not a voice raised in the Supreme Court of Canada:" in favour of excluding certiorari. Even Mr. Justice Rand, who dissented in part on the ground that there was no defect in jurisdiction, held:

The acquiescence of the legislatures, particularly during the last fifty ycars, in the rejection by the courts of such a view confirms the interpretation which has consistently been given to the privative clause.:3

At this point there is one Supreme Court of Canada case which must be dealt with because its imprecision and its failure to rely on or even mention one authority leaves some doubt as to its significance in this area of law.

In Labour Relations Board (British Columbia) v. Canada Safewny Ltd."4 the appellant union applied under the Industrial Conciliation and Arbitration Act:s to the Labour Relations Board for certification as bargaining agent for certain office employees of Canada Safeway Ltd. The latter opposed the application and upon the Board granting the certification, sought by way of certiorari to quash the Board's decision and the certification on the ground that the Board lacked jurisdiction in finding that certain employees were not "employed in a confidential capacity". The British Columbia Court of Appeal:" granted certiorari

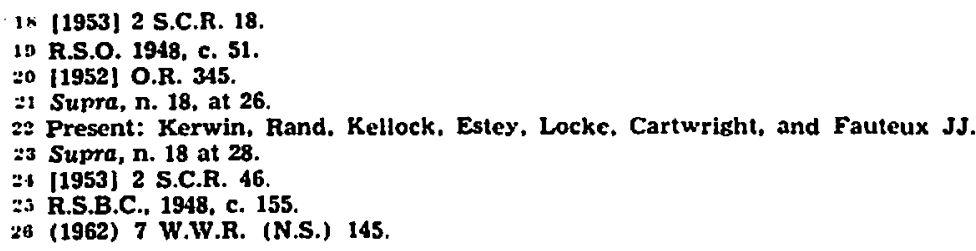


reversing the trial decision. The Supreme Court of Canada allowed the union's appeal. Unfortunately the question of section 2(4) of the said Act was inadequately dealt with.

s. 2(4). If a question arises as to whether a person is an employce within the meaning of this Act the question shall be determined by the Board and the decision of the Board shall be final.

The principal confusion arises in the words of Mr. Justice Taschereau:

I am of the opinion there was sufficient evidence to justify the Board to come to the conclusion that certain comptometer operators and power machine operators were not employed in "a confidential capacity" within the meaning of the Act, and that by virtue of section 2(4) of the Act, its decision is final and is not open to review.27 (Italics supplied)

Mr. Justice Cartwright used similar reasoning.

The question which arises is whether Mr. Justice Taschereau meant that section 2(4) excluded judicial review absolutely. If so it would be in direct conflict with the Globe case.

It is submitted that he did not mean, and that the case is not authority for the proposition, that section $2(4)$ is sufficient to exclude judicial review:

(1) The majority of the Court ${ }^{2 k}$ specifically based their decision on the same ground as Farris CJBC. at trial; that there was sufficient evidence for the Board to come to the conclusion it did. $\mathrm{Mr}$. Justice Kerwin held that on the evidence the Board came to the right conclusion and he expressly excluded the provisions of section 2 (4) from his reasoning. ${ }^{20}$ Hence the ratio of the decision is that there was no absence or defect of jurisdiction and hence no reason to quash rather than that section 2 (4) prevented review;

(2) Section $2(4)$ is not a comprehensive privative clause and does not purport to exclude review generally. It has been held that an assertion that the decision "shall be final" means at most that there is no appeal; ${ }^{30}$

(3) Section 2 (4) is instead an "exclusive jurisdiction" type of clause, to be dealt with later. As will be established later, such clauses can at most prevent upset only in the case of a jurisdictional fact defect.

Thus, the Safeway case does not detract from the Globe proposition that in Canada the comprehensive privative clause is ineffective to exclude judicial review when there is an issue going to jurisdiction.

The obvious question which arises now is why, in the Rammell and Farrell cases, did the court speak in terms of excluding judicial review when the same court in the Globe case affirmed the power to review. The answer is that in the Rammell and Farrell statutes there was something in addition to the comprehensive privative clause; there was also an "exclusive jurisdiction" clause.

\section{EXCLUSIVE JURISDICTION CLAUSES}

Jurisdiction has been aptly termed a "coat of many colours". Courts have quashed administrative decisions for such varied jurisdictional de-

27 Supra, n. 42, at 51.

28 Kermin, Taschereau, Rand, Estey, Cartwright, JJ. with Rinfret C.J. and Kellock J. dissenting.

2y Stpra, n. 24, at 49.

30 Regina v. Medical Appcal Tribunal, Ex parte Gilmore [1957] 1 Q.B. 574. 
fects as no evidence," insufficient evidence, ${ }^{32}$ procedural defect, ${ }^{33}$ and a refusal to hear evidence. ${ }^{34}$ The major jurisdictional defect which concerns us now is that of a defect in the determination of jurisdictional facts.

The theory behind quashing on any of the above grounds is that jurisdiction means authority to decide and no legislative body authorizes a tribunal to act outside this authority. ${ }^{35}$ It is within legislative competence to set the area of this jurisdiction as widely or as narrowly as desired within the limits of constitutionality..$^{30}$ This is the role played by the "exclusive jurisdiction" clauses such as appear in the Rammell and Farrell cases. They are basically nothing more than legislative clarifications of the extent of the jurisdiction which a tribunal has to determine its own jurisdictional facts.

The effect of such clauses is that the tribunal has jurisdiction to determine certain facts and is acting within its jurisdiction in determining them whether rightly or wrongly. Thus it is effective in limiting review on grounds of a jurisdictional fact defect because the statute has in effect stated that there is no defect. It is submitted that this is the basis for the two Supreme Court of Canada decisions under consideration. The legislative history of the jurisdictional fact issue bears out this conclusion.

Jurisdictional facts are facts which must exist prior to a tribunal having jurisdiction; facts which are a condition precedent to jurisdiction. ${ }^{3 i}$ These have encompassed such questions as whether a worker is a member of a trade union, ${ }^{3 R}$ whether a business is that of market gardening, ${ }^{30}$ or whether certain persons are workmen. ${ }^{10}$ It has been recognized that in many instances these are questions of mixed fact and law. ${ }^{11}$

The Classic position is stated in Bunbury v. Fuller: ${ }^{12}$

No Court of limited jurisdiction can give itself jurisdiction by a wrong decision on a point collateral to the merits of the case upon which the limit to its jurisdiction depends: and however its decision may be final on all particulars, making up together that subject-matter which, if true, is within its jurisdiction, and, however necessary in many cases it may be for it to make a preliminary inquiry, whether some collateral matter be or be not within the limits, yet, upon this preliminary question, its decision must always be open to inquiry in the superior court .....

This position was modified in Regina v. Commissioners for Special Purposes of the Income Tax's where Lord Esher MR held:

The legislature may intrust the tribunal or body with a jurisdiction to determine whether the preliminary state of facts exists as well as the jurisdiction, on finding that it does exist, to proceed further or do nothing more."4

a) See De Smlth. Judiclal Revlew of Administrative Action. 66ff. (1st edition, 1959)

3: Sce Re Bland (19341 1 D.L.R. 546 (B.C.S.C.) Children's Aid Society of the Catholic Archdiocese of Vancouver v. Salmon Arm (1941) I D.L.R. 532 (B.C.C.A.): Re Sisters of Charle, Providence Hospital and Labour Relation Board [1951) 3 D.L.R. 735 (Sask. C.A.).

3.. loild.

is Toronto Newspaper Gulld v. Globe Printing Co. supra, n. 18.

ii, See Laskin, loc. cit.

3i Eg. an obvlous constltutlonal IImitation upon the provinces would be they could not give a board Jurlsdlction over federal matters.

37 Segal v. City of Montreal [1931] S.C.R. 460 . Wherkers [1955] 1 D.L.R. 502.

10 Re F. C. Pound Ltd. and Manitoba Labour Board [1955) S D.L.R. 126 (Manitoba Queen's Bench).

sn he Workmen's Comp. Act \& C.P.R. [1950] 2 D. L. R. 630. (Manitoba Queen's Bench)

41 See judgment of Coady J.A. in Farrell case at 446.

12 (1853) $9 \mathrm{Ex}$. 111, 140 .

4321 Q.B.D. 313 (C.A.).

11 Id., at 319 . 
This view has been brought into Canada by the Supreme Court of Canada in Segal v. City of Montreal.": Mr. Justice Lamont stated:

... where the legislature entrusts the tribunal with a jurisdiction which includes the jurisdiction to determine whether the preliminary state of facts exists, as well as the jurisdiction on finding that it does exist to proceed further and do something more. In a case of this kind the jurisdiction is conferred not conditionally upon the facts actually existing, but upon a finding that they do exist. 40

Thus with the proper words a legislature may give to a tribunal jurisdiction to determine its own jurisdictional facts and thereby review will be excluded; not on the basis that such clauses preclude judicial review even if there is an error going to jurisdiction but rather because these clauses provide that there is no error going to jurisdiction. The determination of facts, rightly or wrongly, is within the boards jurisdiction. Our problem now is one of justifying the above analysis in terms of the Rammell and Farrell cases.

\section{THE RAMMELL AND FARRELL CASES}

Thus, on the authority of the Globe case the comprehensive privative clause does not prevent judicial review. In the Rammell and Farrell cases there is a strong privative clause. Since it will not preclude review there must be more to explain the restrictive words of the Supreme Court of Canada. This "more" is the addition of the exclusive jurisdiction clause in Section $76(1)$ :

76(1). The Board shall have exclusive jurisdiction to inquire into, hear, and determine all matters and questions of fact and law arising under this part ...

It is submitted that the court actually proceeded on this basis. This is implicit in Mr. Justice Judson's statement in the Farrell case that even if there was error in law or fact,

$\ldots$ it was made within the exercise of the jurisdiction and is not open to any judicial review including certiorari.t:

This statement must be read keeping in mind the extremely strong exclusionary clause giving not only exclusive jurisdiction to determine all matters of fact and law under Part I but specifically to "inquire into, hear, and determine" such specific matters as "the question whether an injury has arisen out of or in the course of an employment".

That the court proceeded on a jurisdictional fact basis is indicated by its citation of the case of Acme Home Improvements v. Workmen's Compensation Board.8 In that case Mr. Justice Davey of the British Columbia Court of Appeal stated:

.. a most careful examination of the relevant provisions of the British Columbia Act, including section 76, has left us with the firm conclusion that the Board is empowered to adjudicate, rightly or wrongly, upon all questions arising under Part I of the Act....t

In his judgment he gave a well-reasoned analysis of section 76 . In essence it is as follows:

(1) Section $76(1)$ is composed of two parts; one, a comprehensive privative clause providing that there shall be "no certiorari", etc.; the other part conferring upon the Board exclusive jurisdiction to inquire into all matters under Part I of the Act.

ti Supra, note 37 .

11 Id. at 473 .

it Supra, n. 6

4* (1958) 11 D.L.R. (2d) 461 (B.C.C.A.)

4! Id. at 465 . 
(2) The comprehensive privative provision of section $76(1)$ commencing with the words "no proceedings by or before the Board shall be restrained ..." will not exclude judicial review if there is an issue going to jurisdiction.

(3) The problem then is whether the issue before the court is one going to jurisdiction.

(4) The function of the part of section 76(1) conferring exclusive jurisdiction on the Board defines the jurisdiction of the Board; it states that the Board is acting within its jurisdiction in deciding its jurisdictional facts.

(5) Thus since the issue before the court is a jurisdictional fact issue it doesn't go to jurisdiction.

Since there is no issue going to jurisdiction the comprehensive privative clause prevents judicial review on other grounds which would justify review in the absence of such a clause. ${ }^{: 0}$

Thus the two parts of section $76(1)$ complement each other in excluding judicial upset on the basis of a jurisdictional fact issue.

However, this still leaves open the possibility of other jurisdictional defects justifying judicial upset even in the face of section $76(1)$. Such a possibility was in fact realized three years after the Acme case in Battaglia v. Workmen's Compensation Board."1 The Workmen's Compensation Board had denied Battaglia's claim for a pension on the grounds that the silicosis he had contracted did not make him unfit for work. The British Columbia Court of Appeal quashed this decision on the basis that section $54(A)(9)$ of the British Columbia Workmen's Compensation Act provided that a medical specialist shall determine this matter; a medical specialist had determined the matter in Battaglia's favour; and the Board was acting outside its jurisdiction in refusing a pension. In referring to our old friend, section 76 (1) $\mathrm{Mr}$. Justice Davey said:

In my opinion the exclusive authority conferred upon the Board by section 76 (1) to decide questions of law does not extend to the interpretation of those sections of the Act defining the Board's jurisdiction and authority or deprive the superior court of British Columbia of its power to scrutinize the proccedings of the Board to see if it has kept within the jurisdiction and authority conferred upon it by the Act.s?

In light of this statement it is not difficult to imagine some other jurisdictional defect such as one of procedure or declining jurisdiction as justifying upset.

Because of this, section 76 (1) may' not provide any significant limitations upon judicial review at all. In the past the courts have been creative in deeming faults of many kinds to be jurisdictional defects. It would still be open to the courts to hold that even though the decision per se as to the existence of a certain jurisdictional fact is within the exclusive jurisdiction of the Board, there has been some other defect -procedural, evidential or otherwise.

Thus interpreted, the Rammell and Farrell cases do not mean that

:0 It has long been held that privative clauses will prevent upset on the basis of elther breach of natural Justice or error of law on the face of the record; grounds which would be avallable if there were no exclusionary clause.

it (1960) 32 W.W.R. 1 (B.C.C.A.)

it Jd, at 6 \& 7 . 
privative clauses such as in section 76 (1) preclude the courts from reviewing decisions of administrative tribunals. Mr. Justice Judson's statement in the Farrell case that the decision "was made within the exercise of the jurisdiction and is not open to judicial review, including certiorari" indicates that review is still allowable when the decision was made outside the exercise of jurisdiction.

The extent to which such defects are found in future will depend on the judicial temper of the court concerned. In the cases under consideration the Supreme Court of Canada has indicated that it is not so ready to find jurisdictional defect as are some provincial courts. The combined defect of these recent decisions and strong privative clauses as in section $76(1)$ is to narrow the scope of judicial review; but only legislative ingenuity in drafting even more restrictive limitations will result in its total elimination.

SHFLDON M. CHUMIR 